\title{
Readership Behaviour Analysis of Working Women
}

\author{
Shakshi Bisht* and Vandana Verma Trar \\ Department Extension Education and Communication Management, Chaudhary Charan \\ Singh Haryana Agricultural University, Hisar, Haryana, India \\ *Corresponding author
}

\begin{abstract}
A B S T R A C T
\section{Keywords}

Beti Bachao Beti Padhao, Readership, Women, Print media, Reading behaviour

Article Info

Accepted:

20 May 2019

Available Online:

10 June 2019

Readership survey benefits press to know the preference and reading behavior of readers by assessing reading frequency, reading pattern and reading response which is otherwise hard to measure. The study analyzed the working women's reading behavior towards "Beti Bachao Beti Padhao" and also identified the recall ability of BBBP issues published in three major newspapers. Most of the respondents were 30-40 years in age (29\%) belonged to high caste $(50 \%)$ was educated up-to graduate level (38\%) and were married $(60 \%)$. Size of family was medium (38\%), had farming (42\%) as family occupation, monthly income of family was more than 75,000 (38\%). Reading behaviour of majority of respondents was high (40\%) followed by medium (32\%) and low $(28 \%)$. As recall ability is concerned after one week of news article publishing $44 \%$ of the respondents completely recalled the BBBP issues with the help of newspaper cuttings. Education of respondents was significantly associated with reading behaviour at $5 \%$ level of significance.
\end{abstract}

\section{Introduction}

India is second most populous country. It contributes $17.04 \%$ of the world's population while it has only $0.17 \%$ of the total female population. In 2013 UNICEF revealed that after China, India has second worst sex ratio. For the proper growth and development of society and its people and the progress of humanity men and women should not be in discord with each other; rather they should be solidarity and in mutual coordination with each other as they both are incomplete without the other one. It is primary duty as well as concern of every woman to raise the voice and come forward to fight this menace
(Dixit and Jain, 2016). The factors responsible for low Child Sex Ratio (CSR) are educational status of parent, preference of male child, domestic violence and ill treatment by husband and in laws. Sex ratio is inversely proportional to educational status of parents and birth order of child (Jangra et al., 2017). It is also found that majority of women discriminatory issues in society on women are by women. Association between the crime news against women and the response of women towards these news items showed that one of the major concern in the minds of majority of respondents were that they can also be subjected to the same violence as represented in the news stories and it was 
ascertained that the news media (print, electronic and online) is working less in helping the respondents to deal with those fears and more as source of creating those insecurities and fears (Singh, 2016).

Women empowerment correlates with education of girls and women (Prjapati, 2014). Most of the students were motivated by father i.e. 36 percent followed by newspapers i.e. 22 percent, and then by mother 10 percent, self and friends for pursuing their educational goals (Srivastava et al., 2017).

The world is still male dominated, but more women are getting educated and the gap between the men and women education is narrowing. If it continues with same pace then after only few years this gap will be filled (Dalal 2017). Fact that print media are a vehicle to bring change in society cannot be ignored. Therefore in this study it was decided to conduct readership survey of working women on women issues. Readership survey benefits press to know the preference and reading behavior of readers by assessing reading frequency, reading pattern and reading response which is otherwise hard to measure.

The objectives of the study were-

To analyze the readers' behavior towards "Beti Bachao Beti Padhao".

To identify the ability of respondents to recall incidents related to BBBP issues

To measure the association between socioeconomic variables and reader behaviour.

\section{Materials and Methods}

The study was carried out in Hisar city of Haryana state in the year 2014-15; fifty working women were selected randomly. An interview schedule was prepared which had sections to analyze the personal profile of respondents, measure their recall ability and another to measure their readership behaviour. The readership behaviour was tested for significance with personal profile of respondents using chi-square test for independence of attributes.

\section{Results and Discussion}

\section{Profile of respondents}

The profile of respondents in percentage distribution is indicated in table 1.

\section{Age}

Maximum respondents were in 30-40 years (36.00 percent) age group followed by $40-50$ years (24.00 percent), up-to 30 years $(22.00$ percent) and above 50 years (18.00 percent).

\section{Caste}

In total maximum respondents were in high caste (50.00 percent) followed by low (30.00 percent) and medium (20.00 percent) caste.

\section{Education}

Maximum respondents had graduate (38.00) followed by post graduate (32.00) and high school/intermediate (30.00). None of the respondent had only primary level of education.

\section{Marital status}

Majority of respondents (60.00) were married and rest were not.

\section{Type of family}

Equal percent of respondents had joint and nuclear family. 


\begin{tabular}{|c|c|c|c|c|}
\hline \multicolumn{5}{|c|}{ Table.1 Personal Profile of Respondents $(n=50)$} \\
\hline S.No & Variable & & Frequency & Percentage \\
\hline \multirow[t]{4}{*}{1} & \multirow{4}{*}{ Age } & Upto 30 years & 11 & 22 \\
\hline & & $30-40$ years & 18 & 36 \\
\hline & & $40-50$ years & 12 & 24 \\
\hline & & Above 50 years & 9 & 18 \\
\hline \multirow[t]{3}{*}{2} & \multirow{3}{*}{ Caste } & High & 25 & 50 \\
\hline & & Medium & 10 & 20 \\
\hline & & Low & 15 & 30 \\
\hline \multirow[t]{4}{*}{3} & \multirow[t]{4}{*}{ Education } & Primary & 0 & 0 \\
\hline & & High School/Intermediate & 15 & 30 \\
\hline & & Graduate & 19 & 38 \\
\hline & & Post Graduate & 16 & 32 \\
\hline \multirow[t]{2}{*}{4} & \multirow{2}{*}{ Marital Status } & Married & 30 & 60 \\
\hline & & Unmarried & 20 & 40 \\
\hline \multirow[t]{2}{*}{5} & \multirow[t]{2}{*}{ Type of Family } & Nuclear & 25 & 50 \\
\hline & & Joint & 25 & 50 \\
\hline \multirow[t]{3}{*}{6} & \multirow[t]{3}{*}{ Size of Family } & Small & 14 & 28 \\
\hline & & Medium & 19 & 38 \\
\hline & & Large & 17 & 34 \\
\hline \multirow{3}{*}{7} & \multirow{3}{*}{ Family Occupation } & Farming & 21 & 42 \\
\hline & & Service & 16 & 32 \\
\hline & & Business & 13 & 26 \\
\hline \multirow[t]{4}{*}{8} & \multirow{4}{*}{$\begin{array}{l}\text { Family Monthly } \\
\text { Income }\end{array}$} & Less than 25000 & 6 & 12 \\
\hline & & $25,001-50,000$ & 10 & 20 \\
\hline & & $50,001-75,000$ & 15 & 30 \\
\hline & & More than 75,001 & 19 & 38 \\
\hline
\end{tabular}

Table.2 Reading Frequency among respondents Total $(n=50)$

\begin{tabular}{|l|l|c|c|}
\hline S. No & Category & Frequency & Percentage \\
\hline $\mathbf{1}$ & 1-2 Days A Week & 14 & 28 \\
\hline $\mathbf{2}$ & 2-4 Days A Week & 13 & 26 \\
\hline $\mathbf{3}$ & 4-6 Days A Week & 11 & 22 \\
\hline $\mathbf{4}$ & Daily & 12 & 24 \\
\hline
\end{tabular}

\begin{tabular}{|l|l|l|}
\hline \multicolumn{3}{|c|}{ Table.3 Reading response of Respondents } \\
\hline Reading response & Frequency & Percentage \\
\hline Low (7-12) & 12 & 24 \\
\hline Medium (12-17) & 22 & 44 \\
\hline High (17-22) & 16 & 32 \\
\hline
\end{tabular}




\begin{tabular}{|l|l|l|l|}
\hline \multicolumn{4}{|c|}{ Table.4 Reading Pattern among respondents ("multiple responses) } \\
\hline S.No & Category & Total & Rank \\
\hline A & Women/Girl Related Matter Mostly Read in Newspaper & \\
\hline $\mathbf{1}$ & Informative & 34 & I \\
\hline $\mathbf{2}$ & Educative & 30 & II \\
\hline $\mathbf{3}$ & Entertainment & 18 & IV \\
\hline $\mathbf{4}$ & Analytical & 10 & V \\
\hline $\mathbf{5}$ & Crime & 28 & III \\
\hline B & BBBP Issues Liked to be Read & 32 & \\
\hline $\mathbf{1}$ & Views & 21 & I \\
\hline $\mathbf{2}$ & Reviews & 29 & IV \\
\hline $\mathbf{3}$ & Interviews & 18 & VI \\
\hline $\mathbf{4}$ & Editorial & 25 & III \\
\hline $\mathbf{5}$ & Article & 20 & V \\
\hline $\mathbf{6}$ & Feature & & \\
\hline
\end{tabular}

\begin{tabular}{|l|l|l|l|}
\hline \multicolumn{4}{|c|}{ Table.5 Readership Behaviour of Respondents $(\mathrm{n}=50)$} \\
\hline S.No & Category & Frequency & Percentage \\
\hline 1 & Low & 14 & 28 \\
\hline 2 & Medium & 16 & 32 \\
\hline 3 & High & 20 & 20 \\
\hline
\end{tabular}

\begin{tabular}{|c|c|c|c|c|c|}
\hline \multirow{3}{*}{ S.No } & \multicolumn{5}{|c|}{ Table.6 Ability of respondents to recall incidents related to BBBP issues } \\
\hline & \multirow[t]{2}{*}{ Treatment } & \multirow[t]{2}{*}{ Newspaper } & \multicolumn{3}{|c|}{ Recall categories } \\
\hline & & & Completely & Partially & Not at all \\
\hline $\mathbf{A}$ & \multicolumn{5}{|c|}{ After showing clips } \\
\hline \multirow[t]{4}{*}{1} & \multirow{3}{*}{$\begin{array}{l}1 \text { week } \\
\text { after }\end{array}$} & The Times of India & 8 & 8 & 1 \\
\hline & & The Tribune & 9 & 4 & 4 \\
\hline & & Nabh-chor & 5 & 8 & 3 \\
\hline & & Total in \% & 44 & 40 & 14 \\
\hline \multirow[t]{4}{*}{2} & \multirow{3}{*}{$\begin{array}{l}1 \text { month } \\
\text { after }\end{array}$} & The Times of India & 6 & 9 & 2 \\
\hline & & The Tribune & 7 & 5 & 5 \\
\hline & & Nabh-chor & 5 & 7 & 4 \\
\hline & \multicolumn{2}{|r|}{ Total in \% } & 36 & 42 & 22 \\
\hline B & Without sho & ing clips & & & \\
\hline \multirow[t]{4}{*}{1} & \multirow{4}{*}{$\begin{array}{l}1 \text { week } \\
\text { after }\end{array}$} & The Times of India & 6 & 7 & 3 \\
\hline & & The Tribune & 10 & 3 & 6 \\
\hline & & Nabh-chor & 3 & 8 & 4 \\
\hline & & Total in \% & 38 & 36 & 26 \\
\hline \multirow[t]{4}{*}{2} & \multirow{4}{*}{$\begin{array}{l}1 \text { month } \\
\text { after }\end{array}$} & The Times of India & 4 & 10 & 3 \\
\hline & & The Tribune & 7 & 2 & 9 \\
\hline & & Nabh-chor & 5 & 4 & 6 \\
\hline & & Total in \% & 32 & 32 & 36 \\
\hline
\end{tabular}




\begin{tabular}{|c|c|c|c|c|c|c|c|}
\hline \multicolumn{8}{|c|}{ Table.7 Association between profile of respondents and reading behaviour $(n=50)$} \\
\hline S.N & Variable & Low & Medium & High & $\mathbf{x}^{2}$ Cal & d.f & $\mathbf{x}^{2} \mathbf{T a b}$ \\
\hline \multirow[t]{5}{*}{1} & Age & & & & & & \\
\hline & Upto 30 Years & 3 & 2 & 6 & \multirow[t]{4}{*}{6.28} & \multirow[t]{4}{*}{6} & \multirow[t]{4}{*}{12.56} \\
\hline & 31-40 Years & 3 & 6 & 9 & & & \\
\hline & 41-50 Years & 4 & 4 & 4 & & & \\
\hline & Above 50 Years & 4 & 4 & 1 & & & \\
\hline \multirow[t]{4}{*}{2} & Caste & & & & & & \\
\hline & High & 6 & 9 & 10 & \multirow[t]{3}{*}{1.54} & \multirow[t]{3}{*}{4} & \multirow[t]{3}{*}{9.48} \\
\hline & Medium & 3 & 4 & 4 & & & \\
\hline & Low & 5 & 3 & 5 & & & \\
\hline \multirow[t]{4}{*}{3} & Education & & & & & & \\
\hline & High School & 3 & 7 & 5 & \multirow[t]{3}{*}{$11.97^{*}$} & \multirow[t]{3}{*}{4} & \multirow[t]{3}{*}{9.48} \\
\hline & Graduate & 10 & 4 & 5 & & & \\
\hline & Post Graduate & 1 & 5 & 10 & & & \\
\hline \multirow[t]{3}{*}{4} & Marital Status & & & & & & \\
\hline & Married & 9 & 7 & 14 & \multirow[t]{2}{*}{1.49} & \multirow[t]{2}{*}{2} & \multirow[t]{2}{*}{5.99} \\
\hline & Unmarried & 5 & 9 & 8 & & & \\
\hline \multirow[t]{3}{*}{5} & Type Of Family & & & & & & \\
\hline & Nuclear & 8 & 5 & 12 & \multirow[t]{2}{*}{3.33} & \multirow[t]{2}{*}{2} & \multirow[t]{2}{*}{5.99} \\
\hline & Joint & 6 & 11 & 8 & & & \\
\hline \multirow[t]{4}{*}{6} & Size Of Family & & & & & & \\
\hline & Small & 3 & 5 & 6 & \multirow[t]{3}{*}{3.70} & \multirow[t]{3}{*}{4} & \multirow[t]{3}{*}{9.48} \\
\hline & Medium & 6 & 9 & 5 & & & \\
\hline & Large & 5 & 3 & 8 & & & \\
\hline \multirow[t]{4}{*}{7} & Family Occupation & & & & & & \\
\hline & Farming & 5 & 6 & 6 & \multirow[t]{3}{*}{0.426} & \multirow[t]{3}{*}{6} & 12.59 \\
\hline & Service & 4 & 4 & 5 & & & \\
\hline & Business & 5 & 6 & 9 & & & \\
\hline 8 & Monthly Income & & & & & & \\
\hline & Less Than 25000 & 4 & 3 & 3 & 3.08 & 6 & 12.59 \\
\hline & $25,001-50,000$ & 3 & 4 & 6 & & & \\
\hline & $50,001-75,000$ & 4 & 5 & 4 & & & \\
\hline & More Than 75,001 & 3 & 3 & 8 & & & \\
\hline
\end{tabular}

*Significant at 5\% level of significance 
Int.J.Curr.Microbiol.App.Sci (2019) 8(6): 2689-2696

Fig.1 Readership behaviour of respondents

\title{
Readership Behaviour of Respondents $(\mathbf{n = 5 0})$
}

\author{
Low \\ Medium \\ High
}

\section{Size of family}

In total maximum respondents have family size medium (38.00) followed by large (34.00) and small (28.00).

\section{Family occupation}

In total majority of respondents had family occupation as farming (42.00) followed by service (32.00) and business (26.00).

\section{Monthly income of family}

In total maximum number of respondents have family monthly income more than 75,001 (38.00) followed by $50,001-75,000$ (30.00), 25,001-50,000 (20.00) and less than $25,000(12.00)$

\section{Reading frequency among respondents}

Findings regarding frequency to read newspaper in Table 2 indicated that majority of respondents i.e. 28.00 percent respondents are casual readers (readers who read once or twice a week), followed by 26.00 percent of occasional readers (who read two to four days a week), then comes regular readers at 24.00 percent (who read daily) and at last comes the frequent readers (read four to six days a week) are 22.00 per cent

\section{Reading response of respondents}

Reading response of respondents was measured by assessing their response regarding BBBP issues. Discussions done by respondents after reading 'Beti Bachao Beti Padhao' issues and wrote letter to editor were the responses that were observed.

The reading response of respondents regarding $\mathrm{BBBP}$ issues is revealed in table 3 . Majority of respondents have medium (44.00) reading response followed by high (24.00) and least number of respondents (24.00) have low reading response (Fig. 1).

\section{Reading pattern of respondents}

Table 4 pinpoints multiple responses of respondents on the pattern of reading $\mathrm{BBBP}$ issues; mostly read about women / girl issues and the issues that are liked to be read by the respondents. Regarding Women/Girl Related Matter informative issues were mostly read (34), followed by educative (30). Crime issues (28) was also one of the most read issue. Entertainment (18) and analytical (10) were given less importance. In BBBP issues views (32) was most liked to be read followed by interviews (29), article (25) and reviews (21). Feature (20) and editorial (18) were liked by least number of respondents. 


\section{Readership behaviour of respondents}

The readership behaviour is composite of reading frequency, reading response and reading pattern, which in turn had certain parameters. Table 5 shows readership behaviour of the respondents. Majority of respondents (40.00) were belonging to high readership behaviour category followed by medium (32.00) and low (28.00)

\section{Distribution of respondents according to their ability to recall incidents related to BBBP issues}

Data revealed that after showing clips had fewer respondents in not recall at all category when compared to without showing clips in all the three newspapers respectively in both the time periods of after one week and after one month (Table 6).

\section{Association between profile of respondents} and reading behaviour $(n=50)$

Association between profiles of respondents with reading behaviour of the respondents is shown in table 7.

Age (6.28), caste (1.54), marital status (3.392), type of family (6.671) size of family (7.219), family occupation (1.314) and monthly income (7.904) had non-significant association with readership behaviour of respondents. Significant association was found between education (11.97) and readership behaviour of respondents.

Most of the respondents were 30-40 years in age $(29 \%)$ belonged to high caste $(50 \%)$ were educated up-to graduate level (38\%) and were married $(60 \%)$. Size of family was medium (38\%), had farming (42\%) as family occupation, monthly income of family was more than 75,000 (38\%). Reading behaviour of majority of respondents was high (40\%) followed by medium (32\%) and low (28\%). Education of respondents was significant with reading behaviour at $5 \%$ level of significance.

\section{Recommendations}

There is need to have a regular space for publishing positive and developmental issues regarding girls and women, which will help in societal change. The writers and editors need to give attention to create safe feeling to readers.

\section{References}

Census Data, 2011. Govt. of India, Ministry of Home Affairs. Office of Registrar General and Census Commissioner. India. Website: http://www. censusindia.gov.in/2011common/census_2011.html

Dalal, K. 2017. Factors effecting her education. Int Educ \& Research J 3(1): 101-102.

Dixit, M. and Jain, J. 2016. A study of attitude, awareness and practice on female feticide of pregnant women in Udaipur city of Rajasthan. Int $J$ Community Medicine and Public Health. 3(8):2045-2048

Jangra, B., Alla, S. and Majra, J. 2017. The state with lowest sex ratio in India: role of socio - cultural factors. Int $J$ of Community Medicine and Public Health 4:853-856.

Prajapati, M. and Prajapati, B. 2014. Role of education in women empowerment \& development in shahdol division, (M.P.), India. Scholarly Research J. 3(14): 3371-3382.

Singh, K. 2016. Importance of education in empowerment of women in India. Motherhood Inter J of Multidisciplinary Research \& Development. 1(1):39-48

Srivastava, S., Singh, P. and Kumar, M. 2017. 
Situational Effect about Rural Girls in Faizabad District. Int $J$ of Current Microbiology and Appl Sci. 6(2): 1648-
1654.

UNICEF. 2013. Annual official estimate.

\section{How to cite this article:}

Shakshi Bisht and Vandana Verma Trar. 2019. Readership Behaviour Analysis of Working Women. Int.J.Curr.Microbiol.App.Sci. 8(06): 2689-2696.

doi: https://doi.org/10.20546/ijcmas.2019.806.323 